\title{
DEVELOPMENT AND EVALUATION OF A VIRTUAL LEARNING ENVIRONMENT IN PROFESSIONAL NURSING COURSES ${ }^{1}$
}

\author{
Raymunda Viana Aguiar ${ }^{2}$ \\ Silvia Helena De Bortoli Cassiani ${ }^{3}$
}

Aguiar RV, Cassiani SHB. Development and evaluation of a virtual learning environment in professional nursing courses. Rev Latino-am Enfermagem 2007 novembro-dezembro; 15(6):1086-1091.

This study aimed to: develop and evaluate a Virtual Learning Environment in the theme administering medications in a professional nursing course in Curitiba/PR, Brazil. The program's elaboration was divided in three phases: 1-Virtual Learning Environment development Guide. Phase 2, corresponded to implementation and assessment of its use. Phase 3, learning Evaluation. The program evaluations demonstrate that it is in accordance to the educational goals intended to develop and implement an educational technology. The assessment on learning showed that the students answered correctly $85 \%$ of the questions discussed. The possibility of elaborating new educational technologies can be helpful in the teaching/learning process, as well as in the development of future nursing professionals.

DESCRITORS: nursing informatics; education, nursing; educational technology

\section{DESARROLLO Y EVALUACIÓN DE UN AMBIENTE VIRTUAL DE APRENDIZAJE EN CURSOS PROFESIONALIZANTES EN ENFERMERÍA}

Los objetos de este estudio fueron: desarrollar y evaluar el Ambiente Virtual de Aprendizaje en la temática administración de medicamentos en cursos profesionalizantes de enfermería en la ciudad de Curitiba/PR. La elaboración del programa se divide en tres fases: 1 - desarrollo del Ambiente Virtual de Aprendizaje; 2 implementación; 3 - evaluación del aprendizaje. Las evaluaciones del programa demostraron que está en conformidad con los objetivos educacionales propuestos para desarrollo e implementación de una tecnología educacional. La evaluación del aprendizaje demostró que los alumnos alcanzaron un porcentaje de 85\% de aciertos en las cuestiones tratadas. La posibilidad de la elaboración de nuevas tecnologías educacionales serán válidas tanto para auxiliar en el proceso enseñanza/aprendizaje como para desarrollar futuros profesionales de Enfermería.

DESCRIPTORES: enfermería, informática; educación en enfermería; tecnología educacional

\section{DESENVOLVIMENTO E AVALIAÇÃO DE AMBIENTE VIRTUAL DE APRENDIZAGEM EM CURSO PROFISSIONALIZANTE DE ENFERMAGEM}

Os objetivos deste estudo foram: desenvolver e avaliar o ambiente virtual de aprendizagem na temática de administração de medicamentos em Curso Profissionalizante de Enfermagem, na cidade de Curitiba, PR. A elaboração do programa foi dividida em três fases: a primeira fase, desenvolvimento do ambiente virtual de aprendizagem; a fase 2, formatação e avaliação do uso e a fase 3, avaliação da aprendizagem. As avaliações do programa demonstraram que o mesmo está de acordo com os objetivos educacionais propostos para desenvolvimento e implementação de uma tecnologia educacional. A avaliação da aprendizagem demonstrou que os alunos tiveram porcentagem de $85 \%$ de acertos nas questões abordadas. As possibilidades na elaboração de novas tecnologias educacionais serão válidas tanto para auxiliar no processo ensino/aprendizagem como para o desenvolvimento de futuros profissionais na enfermagem.

DESCRITORES: informática em enfermagem; educação em enfermagem; tecnologia educacional

\footnotetext{
${ }^{1}$ Study extracted from Doctoral Dissertation; ${ }^{2}$ RN, Doctoral Student in Nursing at the Interunits Program, University of São Paulo at Ribeirão Preto, College of Nursing, Professor at the Paraná Federal University, Brazil, Technical School, e-mail: raymundaguiar@yahoo.com.br; ${ }^{3}$, RN, PhD in Nursing, Advisor,
} Professor University of São Paulo at Ribeirão Preto, College of Nursing, WHO Collaborating Center for Nursing Research Development, Brazil. 


\section{INTRODUCTION}

Nursing professionals from both technical level and higher education level have been requested to show new competences, besides the ones necessary for the execution of their professional activities, in order to support the changes involving society in the political, social and productive dimensions of human work. To do so, they need to acquire knowledge of new resources provided by the information technologies in their area as a source of information and performance strategy.

Among other aims, educational institutions need to "put their informatics knowledge into practice for the right use of the information systems and technological tools available ${ }^{\prime \prime(1)}$. Thus, the school cannot ignore the reality or move in the opposite direction of market demands. Educators committed to the improvement of education and the creation of capable professionals need to consider the technologies available for improving didactic resources in order to obtain positive results.

In this context, the development of a "virtual learning environment" adds information and communication technologies to the teaching/learning process, offering possibilities of innovation in nursing education. This involves not only informatics use but also the use of the means available, from books to software, since they are in harmony with the educational proposal in the pedagogical process, based on new collaborative e interdisciplinary education methodologies.

Teachers count on a large number of methodological options in the communication and introduction of subjects for evaluation, changing the way of teaching and learning. Thus, "they shall not be afraid of creative innovation, in the constant search for information, nor of understanding that their students are more connected to all of it than the vain despair and unreadiness the teacher usually assumes" $^{\prime(2)}$.

The motivation for the use of technologies in technical nursing courses can be developed from some arguments that range from computer use, as another professional work instrument, to the possibility of knowledge construction, skill acquisition, support for research and recycling. It prepares the professional to face the challenges posed by technological advances in health care, management and information collection.
The communication present in the teaching/ learning process, mediated by informatics, allows for the interaction of contents and interpersonal interaction in an environment that combines technologies and means, always keeping in mind the target public and the content to be presented. Therefore, interactive learning environments offered through the web have some purposes, including: enable the student to decide on the subjects to be explored, the methods and strategies; involve learning in realistic and relevant contexts, which results in genuine experiences, in the integration of students' new ideas into previous knowledge and the development of a colloquial activity through the connection of students with teachers and other participants. Virtual learning environments allow the student to be in control of the learning process ${ }^{(3)}$.

Besides the skill and competence development in the use of new technologies, mediating the pedagogical function, the latter should act as the conductor of the educational process' intermediation, as an interactionist relation between the different actors in the relation: teachers - technology - student.

Vygotsky's historical-cultural theory defines teaching and learning as a human relation, in which the individual benefits from the contribution and orientation of another person more capable of solving issues. The process contributes to the establishment of strategies that shall be used to enable a mediation and organizational relation due to the use of technological instruments, as a conductor of the human relation with the object of the activity. That happens because the competences to be developed, or those an individual is able to perform with someone else's help (more experienced), may solve tasks by imitation and shared experience. The knowledge shared is much more productive and meaningful because it is about the interests of a group and, hence, it will be cooperative knowledge, which is not only useful for one single person, but for a group ${ }^{(4-5)}$.

In the teaching of basic nursing techniques, the individual learns from suggestions, examples and demonstration in an imitation process. According to Vygotsky, a person can only imitate what is at their development level, through the opportunity of (internal) reconstruction of what is observed externally, as the creation of something new, internalizing new information ${ }^{(6)}$.

Based on these concepts, the objectives of this study were defined as: developing and evaluating 
a Virtual Learning Environment - VLE on Medication Administration; implementing the virtual learning environment among students of a Technical Nursing Course; evaluating the knowledge of the students after using the VLE.

\section{METHODOLOGY}

This exploratory-descriptive research aims to observe, describe and express the dimensions of a study object. This article describes the several development stages, the evaluation process of a multimedia educational program in the format of a website, as well as the evaluation process of the student's knowledge as a user of the virtual learning environment.

The elaboration, construction and implementation of an educative multimedia program involve a series of activities, which include the construction of a structure of fundamental elements with the possibility of being revised or reformulated at any time.

Thus, the project was planned, executed and evaluated according to a methodology that articulates the instructional development stages, in a proposal that combines different procedures ${ }^{(7)}$.

The constitutive and defining elements of the environment and its format were: the educational objectives; thematic delimitation; the decision on the scenario to be developed; text formatting; evaluation by experts; implementation and facilitation of its use by the student/user, and finally, student learning evaluation, after the use of the virtual learning environment. Hence, during planning, the sequence of activities, although fixed, does not end in itself.

The research took place in a Technical Nursing Course of a public institution in Curitiba/PR and involved 19 students admitted in 2005. The virtual environment was accessible to students through the platform developed by the Distance Education Center - DES of the Federal University of Paraná - UFPR, created to support both virtual and face-to-face classroom courses.

The elaboration of a virtual learning environment is divided in three stages: learning development, implementation and evaluation.

The first stage addresses the definition of the VLE format, in which the texts about "Medication Administration", and "Didactic Manual" (to guide the use of the program) were elaborated. Five examiners were invited to validate the texts: four Master's and Ph.D.-graduated nurses and a Ph.D. in Education with a specialization degree in Virtual Education, who evaluated the Didactic Manual. All of them contributed with suggestions of changes and information addition. This moment is very important to delimit content, range and depth, keeping in mind the target public of the program.

The following educational objectives were elaborated for the VLE: understand the ethical and legal aspects; understand the fundamental principles and several ways of presenting the medications and their functions; understand the fundamental precautions in medication preparation; understand, identify and define routes for medication administration; medication preparation and administration; understand the general principles of the medication administration technique and necessary procedures; develop ability in the medication administration technique.

After defining the subject, the content delimitation and the educational and instructional objectives, the text was distributed into five modules and 59 pages: Module 1 - Ethical and legal issues and communication in medication administration; Module 2 - Pharmacology Conceptions; Module 3 - Medication Administration Routes; Module 4 - Parenteral Administration 1; Module 5 - Parenteral Intravenous Administration 2.

Once the texts were validated and defined, the second stage of formatting in HTML (Hypertext Protocol) language was started - a computer language for publication and divulgation of text on the web. The pages in hypertext format allow the user to go from one topic or page to another through a link created in topics, based on the conceptual relation among them, in the sequence the user wishes. The links may be: external, taking the user to external topics; or internal, linking topics on the same page or module. This formatting permits the connection among pages, eases the sequence of pages in the modules and the access to thematic topics or continuation to the following stages. After the formatting was finished, the program was made available to the experts in informatics and nursing with a view to a formative evaluation of the prototype.

The group of examiners expert in informatics, two Ph.D.'s and one Master's graduate experienced in educational software development, evaluated the 
items: functionality, usability, efficiency and accessibility. The nursing experts were five Ph.D.'s, three of them experienced in working with and developing educational software. They evaluated the content in the following items: educational objectives, content, relevance and environment.

The instruments used by the examiners for program evaluation were based on the Model of Analytical Appreciation of Hypermedia System ${ }^{(7)}$, aiming to create adapted forms as an instrument to evaluate educational software specific for the informatics and nursing fields.

The second stage covers the implementation of the program in a group of students and the third stage is about the formative evaluation made by the students, referring to the items of the program according to accessibility, usability, functionality, content, relevance and environment. The evaluation of the students' learning after the use of the VLE program was carried out at the end of the first semester of 2008, through an in-class exam, which contained questions on the subjects developed in the modules.

The ethical aspects of this research are in conformity with the ethical regulations established by Resolution No. 196/96 by the Ministry of Health, approved by the Research Ethics Committee at the Health Science Department of the UFPR, registration No. CEP/SD: 125.SM.088/04-11.

\section{RESULTS AND DISCUSSION}

In research or in the teaching/learning process, evaluation considers quantitative and qualitative aspects and searches elements to diagnose difficulties and advances in the educational process, as a way to integrate the educational product and the student in the learning course. Therefore, an evaluation may support teaching, both in the construction of knowledge, methods and methodologies and in student development.

Considering the essential evaluation process in this study as a fundamental part for the development and implementation of the virtual learning environment, it follows the sequence of three evaluation stages.

In the first stage, the texts with the purpose of recognizing coherence, sequence, objectivity, veracity and the quantity of information needed for an educational multimedia program were evaluated ${ }^{(7)}$. The experts presented suggestions of complements and changes, which were accepted and adjusted to the proposal intended for the program.

The second stage refers to the evaluation of the virtual learning environment, made by an expert in informatics and nursing, which addressed aspects separately. The evaluation by the experts in informatics considered that the Virtual Learning Environment was in conformity with the proposal for its elaboration, and that the format was in accordance with requirements for didactic material presentation, as an educational technology for mediating the thematic knowledge used. (Table 1)

Table 1 - Informatics experts' evaluation of the VLE Program. Curitiba, 2005

\begin{tabular}{lccccc}
\hline & GC & C & N & TN & NA \\
\hline Functionality & $47 \%$ & $53 \%$ & $0 \%$ & $0 \%$ & $0 \%$ \\
Usability & $39 \%$ & $61 \%$ & $0 \%$ & $0 \%$ & $0 \%$ \\
Efficiency & $22 \%$ & $78 \%$ & $0 \%$ & $0 \%$ & $0 \%$ \\
Accessibility & $33 \%$ & $67 \%$ & $0 \%$ & $0 \%$ & $0 \%$ \\
\hline
\end{tabular}

GC- great conformity; C- conformity; N- non-conformity; TN- total nonconformity; NA- not applicable

The experts in nursing evaluated: educational objectives, content, relevance and environment. They considered the VLE program suitable to its proposal as a teaching strategy being an Educational Technology and as a mediating element of knowledge and information in the teaching/learning process (Table $2)$. The items identified as in non-conformity were properly changed according to the suggestions, eventually improving the content presented to students of a nursing technical course.

Table 2 - Nursing experts' evaluation of the VLE Program. Curitiba, 2005

\begin{tabular}{lccccc}
\hline & GC & C & N & TN & NA \\
\hline Educational objectives & $40 \%$ & $40 \%$ & $0 \%$ & $0 \%$ & $0 \%$ \\
Content & $38 \%$ & $50 \%$ & $12 \%$ & $0 \%$ & $0 \%$ \\
Relevance & $90 \%$ & $10 \%$ & $0 \%$ & $0 \%$ & $0 \%$ \\
Environment & $20 \%$ & $80 \%$ & $0 \%$ & $0 \%$ & $0 \%$ \\
\hline
\end{tabular}

GC- great conformity; C- conformity; N- non-conformity; TN- total nonconformity; NA- not applicable

The students considered the virtual learning environment in "great conformity" and in "conformity" (Table 3). The difficulties mentioned were the impossibility to access the program in the informatics laboratories of the educational institution, as well as lack of time. The students' evaluation displays the 
certainty that it is possible to offer technologymediated education, despite the difficulties. It also shows the need to improve the computer access conditions, not only for the use of the virtual learning environment, but also as a means to obtain information available on the Web.

Table 3 - Evaluation of the students after using the VLE Program. Curitiba, 2005

\begin{tabular}{lccccc}
\hline & GC & C & N & TN & NA \\
\hline Functionality & $45 \%$ & $49 \%$ & $5 \%$ & $0 \%$ & $0 \%$ \\
Content & $48 \%$ & $47 \%$ & $5 \%$ & $0 \%$ & $0 \%$ \\
Relevance & $40 \%$ & $55 \%$ & $5 \%$ & $0 \%$ & $0 \%$ \\
Usability & $50 \%$ & $48 \%$ & $2 \%$ & $0 \%$ & $0 \%$ \\
Accessibility & $46 \%$ & $50 \%$ & $4 \%$ & $0 \%$ & $0 \%$ \\
Environment & $46 \%$ & $46 \%$ & $8 \%$ & $0 \%$ & $0 \%$ \\
\hline
\end{tabular}

GC- great conformity; C- conformity; N- non-conformity; TN- total nonconformity; NA- not applicable

Students mentioned the acquisition of abilities in the use of the instruments. They reported that the experience was interesting and fundamental for learning. Moreover, they would like to have more subjects available as long as the access was provided in their educational institution, which shows that these students are likely to use communication and information technologies as a means of access to information and learning.

\section{LEARNING EVALUATION}

The learning evaluation should not be understood as an act of measuring or quantifying the learning. It must be a continuous investigation process, aimed at explaining and following up the knowledge acquired by the student as, in every educative action, the objectives proposed for the program are supposed to be accomplished.

The learning evaluation, as a long term knowledge acquired, was planned with a classroom test on the subjects presented in the program. The questions elaborated for this evaluation were taken from the topics covered in the modules with medication administration methods. The intention was to examine the knowledge about these specific techniques, mainly in the practical aspect of the activity.

Learning evaluation using a classroom test is a requirement for the virtual course ${ }^{(3)}$ in order to prove if it is really the student who is going to answer to the questions. The final evaluation aims to investigate the student's learning level in mastering a given content ${ }^{(4)}$. Thus, the test was applied during regular class time, with the 19 students who participated in the research. The result presented an average success rate between $85 \%$ and $90 \%$ in modules 3, 4 and 5, confirming that these students learned the addressed subjects.

\section{FINAL CONSIDERATIONS}

The experience of elaborating a Multimedia Program - Virtual Learning Environment as an educational technology was very important to communicate an idea and the conviction that the use of informatics is not limited any longer. The limit is to know how to use it or not.

Informatics and its resources represent a new paradigm for education, in which the use of multimedia programs and their potentialities allow for the development of the didactic process, through modern technological devices and not merely computer use. The use of knowledge-mediating instruments permits communication and information exchange, through multimedia elements for skills development ${ }^{(5-8)}$.

The Virtual Learning Environment was proposed as an environment mediating teaching and supporting the face-to-face classroom education, using Communication and Information Technologies, for competence acquisition on the execution of techniques, using the computer.

The education of technical nursing professionals should not be limited or devoid of understanding and analysis, or simply determined by mere know-how ${ }^{(9)}$.

The nursing education process corroborates the ideas of Vygostsky, based on the possibility of students learning one from the other, in knowledge acquisition and information exchange in the development process of technical skills. Thus, the use of educational technology offers ways to promote mediated nursing education and, eventually, the opportunity to expand one's knowledge level through the awakening of curiosity ${ }^{(10-12)}$.

More than bringing about considerations and making proposals, this research intended to present the possibilities of a great challenge in the search for new strategies, not only to help the development of our students but also to prepare them for the challenge of continued education, developing new 
abilities and acquiring new competences, and to open up for the possibilities around them in different manifestations.

Finally, we invite all educators and students to start on this trip and surf on the great net of possibilities and information, and to address the knowledge made available either on the web or through existing technological means, not only to help the teaching/learning process but also to develop future professionals, mainly in Nursing.

\section{REFERENCES}

1. Secretaria de Educação Média e Tecnológica (BR). Referências Curriculares Nacionais da educação profissional de nível técnico. Área profissional: Saúde. Brasília (DF): Ministério da Saúde; 2000. [Acesso $10 \mathrm{fev}$ 2005]. Disponível em: URL: http://portal.mec.gov.br.

2. Assmann H. A curiosidade e prazer de aprender: o papel da curiosidade na aprendizagem criativa. Petrópolis (RJ): Vozes; 2004.

3. Coelho MIM. Relação entre referencias pedagógicos e o uso de ferramentas de couserware: desafios ao promover aprendizagem colaborativa on-line. [Acesso em 11 fev 2004]. Disponível em: http://abed.org.br.

4. Vygotsky LS, Luria AR, Leontiiev AN. Linguagem, desenvolvimento e aprendizagem. São Paulo (SP): Ícone; 1988 .

5. Rego TC. Vygotsky: uma perspectiva histórico-cultural da educação. Petrópolis (RJ): Vozes; 1995.

6. Freitas MTA. O pensamento de Vygotsky e Baktin no Brasil. $3^{a}$ ed. Campinas (SP): Papirus; 1994.

7. Struchiner M. Hipermídia na educação: princípios básicos para o desenvolvimento de material educativo. Rio de Janeiro (RJ): NUTES/UFRJ; 1999.

8. Bloon BS. Características humanas e aprendizagem escolar. Porto Alegre (RS): Globo; 1981.

9. Cassiani SHB. Um salto para o futuro no ensino da administração de medicamentos: desenvolvimento de um programa instrucional auxiliado pelo computador. [tese]. Ribeirão Preto (SP): Escola de Enfermagem de Ribeirão Preto/ USP; 1998.

10. Évora YDM. O Paradigma da informática em enfermagem. [Livre-docência]. Ribeirão Preto (SP): Escola de Enfermagem de Ribeirão Preto/USP; 1998.

11. Zem-Mascarenhas SH, Cassiani SHDB. Desenvolvimento e avaliação de um software educacional para o ensino de enfermagem pediátrica. Rev Latino-am Enfermagem 2001 novembro-dezembro: 9(6):13-8.

12. Santos LHP. Vivendo em constante conflito: o significado da prática docente no Ensino Médio de enfermagem. [dissertação] Ribeirão Preto (SP): Escola de Enfermagem/ USP; 1997. 